\title{
ANALISIS AGENCY PROBLEMS, CORPORATE GOVERNANCE, DAN STRUKTUR KEPEMILIKAN PADA PERUSAHAAN-PERUSAHAAN KEUANGAN DI INDONESIA
}

\author{
Wita Juwita Ermawati \\ Institut Pertanian Bogor \\ e-mail :wiet_07@yahoo.com
}

\begin{abstract}
ABSTRAK
Implementation of corporate governance can not be separated from the agency problems that may occur in a company, and the company's ownership structure. Ownership structure of companies in Indonesia including financial firms are likely concentrated (closely held), so that the potential agency problems occur between majority/controlling shareholder and minority shareholders. For the banking sector, potential agency problems occur between owners and depositors (creditors) as well. How the corporate governance run will determine the agency problems that may occur. If there are high agency conflicts, so that corporate governance is not good and there are agency costs that may reduce the value of the company. Agency problems can be minimized through three mechanisms, namely an external mechanism, internal mechanism and market mechanism. Ideally, these three mechanisms can be well implemented. However, the more effective mechanism in ensuring good corporate governance is an external mechanism to oversight and strict law enforcement from regulator and the independent.
\end{abstract}

Key Words: Agency problems, corporate governance, and ownership structure

\section{PENDAHULUAN}

Saat ini perhatian terhadap pelaksanaan good corporate governance khususnya untuk perusahaan-perusahaan keuangan di Indonesia adalah sangat besar. Hal ini terjadi karena perusahaan keuangan adalah merupakan perusahaan yang highly leverage sehingga sangat berpotensi untuk terjadinya masalah keagenan antara pihak-pihak yang terkait. Masalah keagenan dapat menimbulkan biaya keagenan yang pada akhirnya dapat menurunkan nilai perusahaan. Masalah keagenan tidak akan terjadi jika perusahaan melaksanakan tatakelola perusahaan secara baik, atau biasa diistilahkan sebagai good corporate governance. Dengan demikian, jika berbicara mengenai corporate governance, maka tidak terlepas dari apa yang dinamakan teori keagenan.

Dalam teori keuangan, teori keagenan diartikan sebagai pemisahan antara kepemilikan perusahaan dengan kontrol perusahaan. Artinya terdapat pemisahan antara pihak yang memiliki perusahaan dan pihak yang mengontrol atau mengendalikan perusahaan. Pihak yang memiliki perusahaan (shareholder) atau biasa disebut sebagai principal seringkali memiliki kepentingan yang berbeda dengan pihak yang mengendalikan perusahaan (manajer) atau biasa disebut sebagai agen. Karena adanya perbedaan 
kepentingan itulah maka terjadi konflik keagenan antara kedua pihak tersebut. Dalam perkembangannya, konflik keagenan tidak hanya terjadi antara shareholder dan manajer saja, tetapi juga dapat terjadi antara pemegang saham mayoritas atau pengendali (majority atau controlling shareholder) dan pemegang saham minoritas (minority shareholder). Hal tersebut dapat terjadi jika struktur kepemilikan perusahaan adalah terkonsentrasi atau didominasi oleh satu pihak tertentu. Selain itu, masalah keagenan juga dapat terjadi antara pemegang saham (equity holder/shareholder) dan pemegang obligasi (bondholder) ataupun antara pemegang saham pengendali (controlling shareholder) dan pihak yang berkepentingan lainnya (other stakeholders) (Zhuang et. al. dalam Husnan, 2007). Masalah keagenan terjadi jika terdapat informasi yang asimetri atau satu pihak memiliki informasi yang lebih banyak dibandingkan dengan pihak lainnya sehingga pihak yang memiliki informasi lebih banyak akan memanfaatkannya untuk kepentingan dirinya dengan merugikan pihak yang lainnya.

Mengingat pentingnya masalah keagenan yang berpotensi terjadi dalam perusahaanperusahaan keuangan di Indonesia, maka kajian ini dilakukan untuk menganalisis masalah keagenan yang dikaitkan dengan struktur kepemilikan perusahaan dan corporate governance pada perusahaan-perusahaan keuangan di Indonesia, khususnya pada sektor perbankan. Analisis dilakukan terkait dengan struktur kepemilikan dan masalah keagenan yang potensial terjadi, dan juga analisis mengenai mekanisme seperti apa yang efektif dalam menjamin terciptanya good corporate governance sehingga dapat mengurangi masalah keagenan pada perusahaanperusahaan keuangan di Indonesia. Dengan demikian, tujuan yang ingin dicapai pada kajian ini yaitu (1) Mengidentifikasi struktur kepemilikan perusahaan-perusahaan keuangan di Indonesia, (2) Menganalisis masalah keagenan yang terjadi pada perusahaan-perusahaan keuangan di Indonesia, (3) Menganalisis mekanisme-mekanisme tatakelola perusahaan (corporate governance) yang dapat digunakan untuk mengurangi masalah keagenan.

\section{REVIEW LITERATUR DAN HIPOTESIS}

\section{Agency Theory}

Teori keagenan pertama kali dikemukakan oleh Jensen dan Meckling (1976) dalam artikelnya yang berfokus pada implikasi perilaku dari property rights yang dispesifikasikan dalam kontrak antara pemilik (principal) dan manajer perusahaan (agen) dalam menggunakan dan mengontrol sumberdaya. Teori keagenan didasarkan pada premis bahwa agen memiliki lebih banyak informasi dibandingkan principal sehingga memungkinkan terjadinya informasi asimetri yang dapat memberikan efek merugikan terhadap kemampuan principal dalam memonitor agen. Asumsi yang digunakan adalah bahwa principal dan agen akan bertindak rasional untuk memaksimalkan kesejahteraan mereka. Dalam banyak hubungan keagenan antara principal dan agen, akan terjadi biaya pengawasan (monitoring cost), biaya pengikatan (bonding cost), dan residual loss.

Biaya keagenan dapat muncul ketika kepemilikan dan kontrol perusahaan adalah terpisah. Untuk meminimalkan biaya keagenan, perlu didesain kontrak yang optimal antara principal dan agen. Jika dikaitkan dengan pengawasan, kontrak yang optimal akan berbedabeda, yaitu ketika tindakan agen dapat diamati (tidak ada masalah pengawasan), tindakan agen tidak dapat diamati, hanya hasil akhir yang dapat diamati, ataupun ketika kontrak tergantung pada hasil akhir dan ukuran kinerja lain. Jika informasi asimetri antara principal dan agen merupakan inti permasalahan, dapat diuji bagaimanakah struktur kontrak yang optimal yang dapat meminimalkan biaya keagenan. Dengan adanya 
asumsi rasionalitas, agen akan selalu bertindak mengambil peluang yang menguntungkan dirinya dan berlawanan dengan kepentingan principal atau pemilik perusahaan. Hal ini disebut sebagai masalah moral hazard. Sedangkan masalah keagenan lainnya adalah adverse selection, yaitu ketika principal atau pemilik tidak memiliki akses terhadap seluruh informasi yang tersedia pada waktu keputusan dibuat oleh manajer (agen), dimana tidak dapat ditentukan apakah tindakan manajer sesuai atau tidak dengan kepentingan pemilik perusahaan (Scapens dalam Adams, 1994).

\section{Struktur Kepemilikan}

Biaya keagenan terjadi karena adanya pemisahan antara kepemilikan perusahaan dan kontrol perusahaan. Dengan demikian, bagaimana struktur kepemilikan perusahaan dapat menentukan tingkat konflik keagenan dan biaya keagenan yang mungkin terjadi yang berpengaruh terhadap nilai perusahaan. Morck, Nakamura, dan Shivdasani (2000) melakukan studi tentang struktur kepemilikan bank pada perusahaan-perusahaan di Jepang yang dihubungkan dengan nilai perusahaan (firm value) yang diukur dengan menggunakan Tobin's q. Peneliti menemukan bahwa pada tingkat kepemilikan bank yang rendah, nilai Tobin's q menurun dengan peningkatan ekuitas bank. Akan tetapi pada tingkat kepemilikan bank yang lebih tinggi, terdapat hubungan positif antara kepemilikan bank dengan nilai Tobin's q. Pola yang sama terjadi ketika menggunakan ukuran profitabilitas akuntansi sebagai ukuran kinerja.

Masih menurut Morck, Nakamura, dan Shivdasani (2000), nilai perusahaan di Jepang meningkat secara monotonik dengan peningkatan kepemilikan manajerial karena adanya keselarasan antara kepentingan manajerial dan shareholders. Kepemilikan ekuitas secara blok (corporate blockholders) juga berhubungan positif dengan nilai perusahaan di Jepang.
Studi lain yang menguji tentang struktur kepemilikan dilakukan oleh Cebenoyan, Cooperman, dan Register (1999) yang menguji hubungan antara struktur kepemilikan ekuitas, charter value (ukuran nilai perusahaan), dan perilaku pengambilan risiko untuk lembaga simpan pinjam (thrifts) di Amerika antara tahun 1986 hingga 1995, yaitu perioda dimana terjadi perubahan peraturan yang signifikan. Hasil studinya menunjukkan dukungan yang kuat pada hipotesis moral hazard pada perioda dimana peraturan tidak diterapkan dengan baik dan adanya charter value yang rendah. Pada perioda tersebut, tingkat kepemilikan saham manajerial yang tinggi berhubungan dengan unprofitable risk-taking yang lebih besar. Sebaliknya, pada perioda dimana peraturan diterapkan dengan baik dengan charter value yang tinggi, kepemilikan manajerial terkait dengan profitable risk-taking.

La Porta, et al (1999) melakukan studi tentang corporate governance dengan penekanan pada kepemilikan perusahaan dan prakteknya di negara-negara di dunia. Hal pokok yang mendasari penelitian ini adalah adanya pendapat yang ditulis oleh Berle dan Means (1932) yang menjelaskan bahwa terdapat kelaziman kepemilikan yang tersebar di negara Amerika dengan ukuran shareholder yang kecil. Konsekuensi dari kepemilikan tersebar tersebut adalah pengendalian perusahaan terkonsentrasi di tangan manager. Hasil studinya menunjukkan bahwa untuk sampel large firms, dari rata-rata sampel negara, struktur kepemilikan tersebar adalah bukan mayoritas seperti yang disebutkan oleh Berle dan Means, artinya pendapat tersebut adalah misleading. Untuk kedua jenis protection, baik good protection maupun poor protection, jenis kepemilikan principal kebanyakan adalah kepemilikan keluarga dan negara. Jika dibandingkan antara negara dengan good protection dan poor protection, kepemilikan tersebar lebih banyak di negara-negara dengan good protection daripada di negara-negara 
dengan poor protection. Akan tetapi pada negara-negara dengan poor protection, struktur kepemilikannya lebih banyak kepemilikan keluarga dan negara dibandingkan dengan good protection. Perusahaan di negara-negara dengan good protection lebih banyak dikontrol oleh widely held corporation (kepemilikan tersebar), sehingga dapat dikatakan bahwa dispersi dari kepemilikan bergerak bersama-sama dengan good shareholder protection. Untuk sampel medium firms, kepemilikan tersebar semakin sedikit dibandingkan dengan large firms. Hal tersebut dikuatkan dengan kepemilikan keluarga yang semakin meningkat dengan pola kepemilikan yang dominan atau mayoritas.

\section{Corporate Governance}

Husnan (2007) menyebutkan bahwa masalah corporate governance timbul karena terjadi pemisahan antara kepemilikan dan pengendalian perusahaan. Asian Development Bank menjelaskan bahwa "The issue of corporate governance arises because of the separation of ownership from control in modern corporations. When salaried managers run companies on behalf of dispersed shareholders, they may not act inshare holders and managers, but also between controlling and minority shareholders, between shareholders and creditors and between controllingshareholders and other stakeholders; including suppliers and workers. A sound corporate governance sistem should provide effective protection for shareholders and creditors such that they are not denied the return on their investment (Zhuang et. al. 2000)"'. Dari penjelasan tersebut Husnan (2007) menyebutkan bahwa pemilik perusahaan dapat terbagi menjadi dua kelompok, yaitu controlling dan minority shareholders, yang dapat saja terjadi ketidakselarasan kepentingan. Seringkali, seperti di Indonesia dan Korea, karena controlling shareholders mengendalikan manajemen, keputusan-keputusan yang diambil dapat merugikan kepentingan minority shareholders. Masalah keagenan antara manajer dan shareholders dapat terjadi, tetapi masalah tersebut akan lebih banyak terjadi pada perusahaan yang kepemilikannya (sangat) menyebar (manager controlled) daripada yang kepemilikannya relatif terkonsentrasi seperti di Indonesia (owner controlled).

Masih menurut Husnan (2007), sistem corporate governance yang baik seharusnya dapat memberikan perlindungan kepada pemegang saham dan kreditor. Perlindungan ini dapat dilakukan lewat mekanisme dari dalam perusahaan (monitoring dan internal control) maupun lewat mekanisme dari luar. Dua bentuk mekanisme eksternal yang penting adalah bahwa sistem corporate governance tersebut terdiri dari (1) berbagai peraturan yang menjelaskan hubungan antara pemegang saham, manajer, kreditor, pemerintah dan stakeholders yang lain (peraturan yang menjelaskan hak dan kewajiban pihak-pihak tersebut) dan (2) berbagai mekanisme yang secara langsung ataupun tidak langsung menegakkan peraturan-peraturan tersebut. Masalah corporate governance selalu akan muncul sejauh pihak-pihak yang bekerja sama dalam perusahaan mempunyai kepentingan yang berbeda-beda. Di Indonesia nampaknya masalah keagenan yang utama adalah (1) masalah antara pemegang saham pengendali dengan pemegang saham independen dan (2) masalah antara kreditur dan pemilik perusahaan. Berbagai mekanisme baik ekonomi maupun nonekonomi, perlu diciptakan untuk meminimalkan masalah keagenan tersebut. Agar mekanisme tersebut dapat berlangsung dengan baik maka bukan hanya aturan mainnya harus jelas dan tidak bias tetapi penegakan aturan main tersebut juga mutlak diperlukan.

Corporate governance atau tata kelola perusahaan merupakan hal yang sangat penting dan merupakan isu yang banyak dibicarakan dalam corporate finance. Pertanyaan mendasar 
dari corporate governance adalah bagaimana memastikan pemilik dana bahwa mereka akan mendapat return dari investasi mereka. Shleifer dan Vishny (1997) menyebutkan bahwa terkait dengan hal tersebut, masalah keagenan merupakan masalah yang serius, dimana peluang manajer untuk melarikan diri dengan dana pemodal atau memboroskan dana tersebut pada proyek yang tidak menguntungkan adalah banyak terjadi. Untuk mengatasi hal tersebut, peneliti menyebutkan pendekatan yang dapat digunakan dalam corporate governance, diantaranya adalah kemungkinan pendanaan berdasarkan pada reputasi manajer atau berdasarkan pada harapan investor yang sangat optimistik tentang kemungkinan untuk mendapatkan dana mereka kembali. Selain itu, proteksi legal untuk investor dan konsentrasi kepemilikan adalah merupakan pendekatan komplementer untuk governance. Kepemilikan yang terkonsentrasi (melalui share holdings, takeovers, dan pendanaan bank) juga merupakan metoda yang hampir universal untuk mengontrol dan membantu investor untuk mendapatkan kembali uangnya. Namun demikian meskipun investor yang besar dapat sangat efektif dalam menyelesaikan masalah keagenan, tetapi mereka dapat meredistribusi kekayaan dengan tidak efisien dari investor lain ke mereka sendiri.

Shleifer dan Vishny (1997) melakukan survey mengenai corporate governance dengan menggunakan perspektif keagenan, yang mengacu pada pemisahan antara kepemilikan dan kontrol atau antara pendanaan dan pengelolaan. Hasil surveynya menunjukkan bahwa sistem corporate governance yang sukses adalah sistem yang diterapkan di US, Jerman, dan Jepang, yang mengkombinasikan proteksi legal yang signifikan dari paling tidak beberapa investor dengan peran penting untuk banyak investor. Kombinasi ini membedakan mereka dari sistem governance pada kebanyakan negara-negara lain, yang memberikan proteksi legal yang sangat terbatas untuk investor, dan terjebak dengan keluarga dan insider yang mendominasi perusahaan dengan menerima sedikit pendanaan eksternal.

La Porta, et al pada tahun 2000 juga melakukan studi lanjutan tentang corporate governance. Studi ini juga menekankan pada pentingnya proteksi bagi investor dan sistem legal dalam suatu negara. Disebutkan bahwa penelitian terbaru tentang corporate governance di dunia telah menghasilkan sejumlah keteraturan empiris. Elemen-elemen yang berbeda dari sistem pendanaan di negara-negara di dunia, seperti keluasan dan kedalaman pasar modal, kecepatan penerbitan sekuritas baru, struktur kepemilikan perusahaan, kebijakan dividen, dan efisiensi dari alokasi investasi dapat dijelaskan secara konseptual dan secara empiris oleh seberapa baik hukum dalam negara tersebut memproteksi outside investor. Menurut penelitian-penelitian tersebut, proteksi untuk shareholder dan kreditor oleh sistem legal merupakan hal yang sentral untuk memahami pola dari pendanaan perusahaan pada negara-negara yang berbeda. Outside investor yang mendanai perusahaan akan menghadapi risiko bahwa return dari investasi mereka tidak akan pernah terwujud karena controlling shareholders atau manajer (insider shareholders) akan mengekspropriasi mereka. Corporate governance pada batas tertentu adalah merupakan suatu mekanisme dimana outside investor memproteksi mereka sendiri terhadap ekspropriasi yang mungkin dilakukan oleh insider.

La Porta et al., (2000) menyebutkan bahwa proteksi legal untuk investor merupakan cara berfikir yang bermanfaat mengenai corporate governance. Proteksi investor yang kuat dapat merupakan manifestasi penting dari greater security atas property rights melawan gangguan politis yang terjadi di beberapa negara. Dengan menggunakan proteksi investor sebagai titik awal merupakan cara yang lebih bermanfaat untuk menggambarkan perbedaan dalam cara atau aturan corporate governance daripada 
klasifikasi biasa seperti keterpusatan bank atau pasar. Secara umum, regulasi dari pasar keuangan adalah sangat berakar pada struktur legal di setiap negara dan origin dari laws-nya.

Untuk kasus di Indonesia, studi tentang pengaruh corporate governance terhadap kinerja keuangan bank di Indonesia dilakukan oleh Supriyatno (2006). Hasil penelitian menunjukkan bahwa external corporate governance (ECG) berpengaruh signifikan terhadap kinerja sebagai cerminan pelaksanaan good external corporate governance. Pengaruh positif ECG terhadap kinerja pada bank swasta terbuka mencerminkan bahwa kepemilikan terbuka/publik di samping mampu memenuhi kepentingan regulator sebagai representasi kepentingan publik, juga mampu mendisiplinkan manajemen dalam upaya maksimisasi kesejahteraan pemilik. Namun demikian, ECG pada bank swasta tertutup dan bank pemerintah berpengaruh negatif terhadap kinerja yang menunjukkan bahwa kedua bentuk kepemilikan tersebut sekalipun mampu dalam memenuhi kepentingan regulator namun belum cukup mampu memenuhi kepentingan pemilik. Hal tersebut mengindikasikan kurang adanya pengaruh pasar dalam upaya mendisiplinkan manajemen bank pada kedua bentuk kepemilikan tersebut. Akan tetapi penelitian ini belum dapat memberikan bukti yang kuat bahwa internal corporate governance (ICG) berpengaruh terhadap kinerja. Selain itu penelitian ini memberikan bukti bahwa bentuk-bentuk kepemilikan memoderasi pengaruh good ECG terhadap kinerja bank pada semua bentuk kepemilikan, namun tidak demikian halnya dengan good ICG.

Studi lain dilakukan oleh Gunarsih (2003) yang bertujuan untuk memberikan bukti empiris mengenai seberapa jauh fenomena corporate governance di Indonesia mempengaruhi kinerja dengan menguji pengaruh proporsi kepemilikan oleh institusi terhadap kinerja perusahaan. Secara umum disimpulkan bahwa struktur kepemilikan berpengaruh padakinerja perusahaan. Konsentrasi proporsi kepemilikan perusahaan publik oleh institusi domestik berpengaruh negatif terhadap kinerja perusahaan sedangkan kepemilikan asing berpengaruh sebaliknya. Hal ini mengindikasikan bahwa permasalahan keagenan utama yang terjadi adalah antara pemilik institusi domestik dengan pemilik minoritas. Selain itu juga terlihat bahwa upaya untuk menyelenggarakan good corporate governance sudah diikuti oleh sebagian besar perusahaan, yang ditunjukkan oleh adanya Komite Audit dan Komisaris Independen.

\section{HASIL PENELITIAN DAN PEMBAHASAN}

\section{Agency Problems dan Struktur Kepemilikan untuk Perusahaan Keuangan di Indonesia}

Masalah keagenan merupakan masalah yang banyak terjadi di perusahaan baik perusahaan keuangan maupun non keuangan. Konflik keagenan ini terjadi karena adanya pemisahan antara kepemilikan perusahaan dan pengontrolan perusahaan. Artinya pemilik perusahaan (principal) tidak ikut mengontrol dan mengendalikan perusahaan, di lain pihak manajer (agen) yang mengendalikan perusahaan adalah bukan pemilik perusahaan sehingga berpotensi untuk menimbulkan konflik karena tidak adanya keselarasan kepentingan antara principal dan agen tersebut, yang pada akhirnya dapat menurunkan nilai perusahaan. Oleh karena itu, struktur kepemilikan perusahaan berperan penting dalam menentukan tingkat konflik keagenan yang mungkin terjadi. Dalam menganalisis konflik keagenan, penting untuk mengidentifikasi terlebih dahulu pihak-pihak mana yang berkonflik secara dominan sehingga upaya-upaya yang dilakukan untuk meminimalkan konflik tersebut dapat lebih mengena.

Berdasarkan data dari Indonesian Capital Market Directory (2011) dan studistudi sebelumnya menunjukkan bahwa struktur kepemilikan perusahaan-perusahaan di Indonesia 
adalah cenderung terkonsentrasi (closely held) dengan mayoritas kepemilikan lebih dominan dikuasai oleh keluarga. Kondisi ini sesuai dengan studi yang dilakukan oleh La Porta, et al. (1999) bahwa di banyak negara (khususnya adalah negara-negara berkembang) struktur kepemilikan adalah terkonsentrasi dengan mayoritas kepemilikan keluarga. Dengan demikian, konflik keagenan yang mungkin terjadi adalah antara pemilik mayoritas (majority shareholders) atau pemegang saham pengendali (controlling shareholder) dan pemilik minoritas. Pemilik mayoritas berpotensi untuk melakukan ekspropriasi terhadap pemilik minoritas. Artinya bahwa pemilik mayoritas dapat mengambil keuntungan untuk dirinya karena daya tawar dan juga informasi yang mereka miliki lebih banyak (terjadi informasi yang asimetri) dibandingkan dengan pemilik minoritas sehingga merugikan pemilik minoritas.

Studi La Porta, et al. (1999) menunjukkan bahwa kepemilikan keluarga sering memiliki hak kontrol yang dominan dan signifikan atas perusahaan melebihi hak cash flow-nya. Artinya kontrol yang diberikan terhadap perusahaan tersebut sangat dominan melebihi proporsi modal yang dimilikinya pada perusahaan tersebut. Keluarga juga seringkali ikut dalam manajemen untuk mengelola perusahaan yang mereka kontrol. Fenomena ini juga terjadi pada perusahaan-perusahaan di Indonesia. Keluarga sangat mendominasi jalannya operasional perusahaan bahkan memungkinkan terjadinya ketidakjelasan batas antara kepentingan keluarga dan kepentingan profesional perusahaan. Husnan (2007) menyebutkan bahwa ketidakmampuan atau kurangnya kompetensi anggota keluarga yang ikut mengelola perusahaan juga merupakan masalah tersendiri yang pada akhirnya dapat menimbulkan kerugian atau penurunan nilai perusahaan.

Aturan perseroan terbatas di Indonesia yang menyebutkan adanya limited liability of owners, yaitu kewajiban yang terbatas hanya pada modal disetor tanpa menjaminkan kekayaan pribadinya juga dapat menjadi faktor yang menyebabkan timbulnya konflik keagenan antara pemegang saham mayoritas dan pemegang saham minoritas. Pemilik mayoritas dapat mengambil investasi yang berisiko tinggi tanpa mempertimbangkan kepentingan minoritas, karena tidak ada kekhawatiran bahwa kekayaan pribadinya akan dijaminkan atau diambil jika terjadi kerugian dari investasi yang berisiko tersebut (Husnan, 2007). Disebutkan juga bahwa pemilik mayoritas yang umumnya didominasi keluarga umumnya ingin mempertahankan proporsi kepemilikannya, sehingga keputusan pendanaan yang dilakukan cenderung lebih menggunakan utang dibandingkan dengan penerbitan ekuitas. Dalam beberapa kasus terdapat kelompok usaha keluarga yang melebarkan usahanya dengan mendirikan bank sehingga perusahaan tersebut memiliki keleluasaan untuk mendapatkan dana utang dan tidak menggunakan mekanisme perbankan seperti yang seharusnya. Dari sini sangat terlihat bahwa terdapat potensi terjadinya konflik keagenan yang sangat tinggi akibat adanya kepemilikan yang cenderung terkonsentrasi.

Kondisi yang sama juga terjadi untuk perusahaan keuangan seperti perbankan. Menurut data dari Indonesian Capital Market Directory (2011), struktur kepemilikan untuk perusahaan keuangan di Indonesia mayoritas adalah terkonsentrasi, artinya lebih dari 50\% saham dimiliki oleh satu pihak, baik itu perusahaan maupun keluarga (untuk perusahaan keluarga mungkin kepemilikan tidak lebih dari 50\% tetapi mayoritas adalah dimiliki keluarga). Hal ini menyebabkan terjadinya masalah keagenan karena keputusan-keputusan bank, misalnya terkait dengan pemberian kredit kepada debitor cenderung tidak didasarkan pada prinsip-prinsip perbankan yang semestinya. Dari perusahaanperusahaan keuangan yang terdaftar pada 
Bursa Efek Indonesia (BEI), mayoritas adalah perusahaan dengan kepemilikan terkonsentrasi. Pemilik mayoritas dan besarnya kepemilikan perusahaan-perusahaan keuangan dengan kepemilikan terkonsentrasi menurut data dari Indonesian Capital Market Directory (2011) (tidak termasuk perusahaan yang dimiliki pemerintah) dapat dilihat pada Lampiran 1 - 4 . Dari tabel tersebut terlihat bahwa secara umum lebih dari 50 persen perusahaan keuangan yang kepemilikannya didominasi oleh satu pihak dan cenderung keluarga, yang dapat memicu terjadinya konflik keagenan.

Fungsi utama perbankan adalah sebagai lembaga intermediari antara pihak yang menyimpan dananya di bank dan pihak yang meminjam dana dari bank. Tentunya bank memiliki risiko dimana debitur tidak memenuhi kewajibannya kepada kreditor, dalam hal ini pihak perbankan. Oleh karena itu bank harus membuat suatu mekanisme dengan prinsip kehati-hatian yang dapat meminimalkan risiko gagal bayar tersebut. Namun demikian sangat mungkin terjadi pemberian kredit tersebut tidak mengikuti aturan yang seharusnya, apalagi jika bank tersebut dimiliki oleh keluarga dan pihak yang meminjam dana juga adalah kelompok usaha keluarga tersebut. Pada kasus tersebut, masalah keagenan yang banyak terjadi adalah antara pemilik mayoritas dan minoritas juga, dimana terdapat potensi pemilik bank memanfaatkan wewenangnya untuk memberikan kredit kepada kelompok usahanya tanpa mempertimbangkan kemampuan membayar perusahaan debitur, sehingga jika terjadi gagal bayar, pemilik minoritas akan dirugikan.

Selain konflik keagenan antara pemegang saham mayoritas dan minoritas, pada sektor perbankan juga dapat terjadi masalah keagenan antara pemilik perusahaan dan deposan (kreditur bank). Husnan (2007) menyebutkan bahwa pemilik perusahaan (diwakili oleh manajer) dapat mengambil keputusan-keputusan keuangan yang berisiko, baik itu dalam pemberian kredit maupun investasi keuangan lainnya. Jika keputusan keuangan tersebut tepat dan memberikan keuntungan, maka pemilik dan deposan (kreditur) akan mendapatkan manfaatnya. Akan tetapi jika keputusan keuangan tersebut tidak tepat dan memberikan kerugian, maka deposan (kreditur) memiliki risiko ikut menanggung kerugian tersebut. Jadi dalam hal ini deposan dirugikan oleh kepentingan pemilik perusahaan.

\section{Mekanisme untuk Mengurangi Agency Problems dan Terciptanya Good Corporate Governance}

Penting bagi perusahaan untuk meminimalkan masalah keagenan dan biaya keagenan karena dapat menurunkan nilai perusahaan. Salah satu cara untuk mengurangi masalah keagenan adalah dengan memperhatikan struktur kepemilikan yang ada di perusahaan keuangan. Salah satu mekanisme yang dibuat oleh Bank Indonesia terkait dengan struktur kepemilikan adalah adanya peraturan mengenai kepemilikan tunggal pada perbankan Indonesia yang dituangkan dalam Peraturan Bank Indonesia nomor 8/16/PBI/2006, bahwa untuk mewujudkan struktur perbankan Indonesia yang sehat dan kuat serta untuk mendukung efektivitas pengawasan bank maka hanya diizinkan suatu pihak hanya menjadi pemegang saham pengendali (pemegang saham mayoritas) pada satu bank saja. Pemegang saham pengendali yang dimaksud adalah badan hukum dan atau perorangan dan atau kelompok usaha yang (a) memiliki saham bank sebesar 25\% atau lebih dari jumlah saham yang dikeluarkan bank dan mempunyai hak suara; (b) memiliki saham bank kurang dari 25\% dari jumlah saham yang dikeluarkan bank dan mempunyai hak suara namun dapat dibuktikan telah melakukan pengendalian bank baik secara langsung maupun tidak langsung. Namun ketentuan tersebut dikecualikan bagi (a) pemegang saham pengendali pada dua bank yang masing- 
masing melakukan kegiatan usaha dengan prinsip berbeda, yakni secara konvensional dan berdasarkan prinsip syariah; (b) pemegang saham pengendali pada dua bank yang salah satunya merupakan bank campuran (joint venture bank); (c) bank holding company, yaitu badan hukum yang dibentuk dan atau dimiliki oleh pemegang saham pengendali untuk mengkonsolidasikan dan mengendalikan secara langsung seluruh aktivitas bank-bank yang merupakan anak perusahaannya. Dengan mematuhi peraturan tersebut, dominasi pemilik saham mayoritas atau saham pengendali diharapkan dapat berkurang, yang pada akhirnya dapat mengurangi konflik keagenan yang mungkin timbul antara pemilik mayoritas dan minoritas.

Selain mematuhi peraturan Bank Indonesia terkait dengan komposisi pemilik saham pengendali, dalam rangka menjamin pelaksanaan good corporate governance pada operasionalisasi perbankan, tentunya setiap bank umum juga harus mematuhi peraturan Bank Indonesia Nomor 8/4/PBI/2006 tentang pelaksanaan Good Corporate Governance bagi bank umum yang mempertimbangkan (a) bahwa dengan semakin kompleksnya risiko yang dihadapi bank, maka semakin meningkat pula kebutuhan praktek good corporate governance oleh perbankan; (b) bahwa dalam rangka meningkatkan kinerja bank, melindungi kepentingan stakeholders dan meningkatkan kepatuhan terhadap peraturan perundang-undangan yang berlaku serta nilainilai etika yang berlaku umum pada industri perbankan, diperlukan pelaksanaan good corporate governance; dan (c) bahwa peningkatan kualitas pelaksanaan good corporate governance merupakan salah satu upaya untuk memperkuat kondisi internal perbankan nasional sesuai dengan Arsitektur Perbankan Indonesia (API).

Good Corporate Governance yang dimaksud dalam peraturan ini adalah suatu tata kelola bank yang menerapkan prinsip-prinsip keterbukaan (transparency), akuntabilitas (accountability), pertanggungjawaban (responsibility), independensi (independency), dan kewajaran (fairness). Bank wajib melaksanakan prinsip-prinsip Good Corporate Governance dalam setiap kegiatan usahanya pada seluruh tingkatan atau jenjang organisasi. Pelaksanaan prinsip-prinsip Good Corporate Governance tersebut paling tidak harus diwujudkan dalam hal (a) pelaksanaan tugas dan tanggung jawab Dewan Komisaris dan Direksi; (b) kelengkapan dan pelaksanaan tugas komite-komite dan satuan kerja yang menjalankan fungsi pengendalian intern bank; (c) penerapan fungsi kepatuhan, auditor internal dan auditor eksternal; (d) penerapan manajemen risiko, termasuk sistem pengendalian intern; (e) penyediaan dana kepada pihak terkait dan penyediaan dana besar bank wajib menerapkan prinsip kehati-hatian; (f) rencana strategis bank dimana bank wajib menyusun rencana strategis dalam bentuk rencana korporasi (corporate plan) dan rencana bisnis (business plan); dan (g) transparansi kondisi keuangan dan non keuangan bank kepada Stakeholders. Selain itu, bank juga wajib memastikan ketersediaan dan kecukupan pelaporan internal yang didukung oleh sistem informasi manajemen yang memadai untuk menjamin kualitas keputusan yang diambil oleh dewan direksi. Bank juga perlu melaporkan pelaksanaan Good Corporate Governance dan melakukan penilaian mengenai pelaksanaan Good Corporate Governance (Self Assessment) pada bank-nya masing-masing.

Selain peraturan mengenai dari Bank Indonesia, komite nasional kebijakan corporate governance pada tahun 2004 juga mengeluarkan pedoman mengenai pelaksanaan good corporate governance untuk perbankan di Indonesia. Pedoman terebut dapat digunakan sebagai acuan perbankan Indonesia dalam menjalankan praktek good corporate governance.

Namun demikian, jika dilihat dari aspek hukum yang berlaku (law origin), negara Indonesia termasuk ke dalam kelompok civil law, 
yang memberikan proteksi yang lemah (poor protection) terhadap pemegang saham minoritas (La Porta, et al., 1999, 2000). Kondisi yang poor protection ini dapat diartikan sebagai lemahnya perlindungan terhadap kepentingan pemilik saham minoritas atau outside investor, ataupun perlindungan terhadap kreditur. Oleh karena itu, walaupun sudah ada peraturan dari Bank Indonesia mengenai pelaksanaan good corporate governance pada sektor perbankan, yang lebih penting adalah bagaimana pelaksanaan dan penegakan hukum atas peraturan tersebut. Bagaimana proses monitoring dalam hal pelaksanaan good corporate governance dapat dijalankan secara efektif sehingga kinerja perbankan ataupun perusahaan keuangan lainnya tetap dapat baik dan tidak menimbulkan konflik atau masalah keagenan. Dengan demikian, peran regulator dalam hal ini adalah Bank Indonesia dan Otoritas Jasa Keuangan sangat penting dalam hal penegakan hukum demi terciptanya pelaksanaan good corporate governance untuk sektor perbankan dan perusahaan keuangan pada umumnya.

Salah satu proses monitoring yang dapat dilakukan adalah dengan melibatkan pihakpihak yang independen dalam operasionalisasi perusahaan keuangan tersebut. Diantaranya yaitu dengan pengangkatan komisaris independen, pihak independen dan komite audit yang independen, sesuai dengan peraturan Bank Indonesia Nomor 8/4/PBI/2006 dan surat edaran Bank Indonesia Nomor 9/12/DPNP tanggal 30 Mei 2007 tentang pelaksanaan good corporate governance bagi bank umum. Jika tidak ada pihak yang independen yang mengawasi jalannya operasional perusahaan keuangan tersebut, maka sulit untuk menjamin terciptanya pelaksanaan sistem tatakelola perusahaan yang baik (good corporate governance).

Mekanisme penjaminan pelaksanaan good corporate governance yang diuraikan sebelumnya adalah lebih cenderung bersifat mekanisme eksternal. Di sisi lain, mekanisme internal dalam hal pelaksanaan tatakelola perusahaan yang baik juga penting untuk dilakukan. Hal ini dapat terjadi jika perusahaan memiliki visi dan value untuk senantiasa menjalankan operasional perusahaan demi kepentingan semua stakeholder, dan tidak hanya untuk kepentingan shareholder atau pihak tertentu saja. Dengan demikian selalu diupayakan agar sistem tatakelola yang dilaksanakan adalah tatakelola perusahaan yang baik yang meminimalkan konflik dan biaya keagenan yang mungkin timbul.

Selain itu, pasar juga dapat menjalankan perannya sebagai mekanisme kontrol bagi perusahaan-perusahaan keuangan. Pasar dapat bereaksi secara positif terhadap perusahaan yang menjalankan good corporate governance, dan sebaliknya, dapat bereaksi secara negatif terhadap perusahaan yang menjalankan bad corporate governance. Namun demikian, mekanisme kontrol oleh pasar ini terkadang tidak berjalan secara efektif, karena bisa saja pasar tidak mengetahui semua informasi yang terjadi di perusahaan, terutama untuk perusahaanperusahaan yang bukan merupakan perusahaan publik (private company). Pasar juga dapat menangkap sinyal yang diberikan perusahaan secara salah sehingga memberikan reaksi yang berlebihan atau tidak tepat. Oleh karena itu, dari ketiga mekanisme yang dapat digunakan untuk menjamin pelaksanaan good corporate governance pada perusahaan-perusahaan keuangan di Indonesia, idealnya ketiga mekanisme tersebut dapat berjalan dengan baik. Akan tetapi yang lebih efektif dalam memantau pelaksanaan good corporate governance adalah mekanisme eksternal dengan kesadaran para regulator untuk menjamin penegakan hukum dan peraturan secara baik dengan keterlibatan pihak independen dalam mengawasi atau memonitornya. 


\section{KESIMPULAN DAN SARAN}

\section{Kesimpulan}

Penerapan corporate governance tidak terlepas dari masalah keagenan yang mungkin terjadi pada suatu perusahaan dan bagaimana struktur kepemilikan perusahaan tersebut. Struktur kepemilikan perusahaan-perusahaan di Indonesia termasuk perusahaan keuangan adalah cenderung terkonsentrasi, sehingga masalah keagenan yang potensial tejadi adalah antara pemegang saham mayoritas/pengendali (majority/controlling shareholder) dan pemegang saham minoritas (minority shareholder). Selain itu, untuk sektor perbankan juga mungkin terjadi masalah keagenan antara pemilik perusahaan dan deposan (kreditur). Semua masalah keagenan tersebut berpangkal pada proses tatakelola yang dijalankan oleh perusahaan (corporate governance). Jika terdapat masalah keagenan yang berat atau serius, berarti corporate governance yang dijalankan adalah tidak bagus dan mengakibatkan timbulnya biaya keagenan sehingga dapat menurunkan nilai perusahaan.

Masalah keagenan yang muncul dapat diminimalkan melalui tiga mekanisme, yaitu mekanisme eksternal, mekanisme internal dan mekanisme pasar. Mekanisme eksternal yaitu dengan penegakan hukum dari regulator terkait dengan aturan mengenai struktur kepemilikan perusahaan keuangan dan penjaminan pelaksanaan good corporate governance dengan pengawasan atau monitoring yang ketat dari pihak yang independen. Mekanisme internal yaitu dengan kesadaran dari pihak internal perusahaan untuk senantiasa berupaya melaksanakan sistem tatakelola yang baik untuk kepentingan semua stakeholders. Sedangkan mekanisme yang ketiga adalah mekanisme pasar dimana pasar yang mengawasi pelaksanaan tatakelola perusahaan. Idealnya adalah ketiga mekanisme tersebut dapat dilaksanakan secara baik. Akan tetapi mekanisme yang lebih efektif dalam menjamin terciptanya good corporate governance adalah mekanisme eksternal dengan pengawasan dan penegakan hukum yang ketat dari regulator dan pihak independen.

\section{Saran}

- Perlunya perhatian yang lebih dari regulator untuk memberikan perlindungan terhadap pemilik saham/investor minoritas atau outside investor dalam bentuk aturan hukum yang berlaku sehingga dapat meminimalkan masalah keagenan yang mungkin terjadi.

- Perusahaan secara internal harus senantiasa melakukan praktek good corporate governance dengan dukungan pengawasan dan penegakan hukum yang ketat dari regulator dan pihak independen.

\section{DAFTAR PUSTAKA}

Adams, M.B. 1994. "Agency Theory and The Internal Audit". Managerial Auditing Journal, 9 (8), 8-12.

Anderson, R.C., Fraser, D.R.. 2000. "Corporate Control, Bank Risk Taking, and The Health of The Banking Industry". Journal of Banking and Finance, 24, 1383-1398.

Cebenoyan, A.S., Cooperman, E.S., Register, C.A. 1999. "Ownership Structure, Charter Value, and Risk-Taking Behavior for Thrifts". Financial Management, 28 (1), 43-60.

Gunarsih, T.2003.Pengaruh Struktur Kepemilikan dalam Corporate governance dan Strategi Diversifikasi Terhadap Kinerja Perusahaan. Disertasi pada Fakultas Ekonomika dan Bisnis, Universitas Gadjah Mada, Yogyakarta.

Husnan, Suad. 2007. Corporate Governance $d i$ Indonesia. Pengamatan Terhadap Sektor Korporat dan Keuangan. http://matakuliah.files.wordpress. com/2007/09/perekin-2.pdf (Diunduh tanggal 16 Juni 2012). 
Indonesian Capital Market Directory. 2011. Institute for Economic and Financial Research. Jakarta.

Jensen, Michael, C., and Meckling, William, H. 1976. "Theory of the firm: managerial behavior, agency costs and ownership structure". Journal of Financial Economics. 305-360.

Komite Nasional Kebijakan Corporate Governance. 2004. Pedoman Good Corporate Governance Perbankan Indonesia.

Laporta, R.,Lopez-de-Silanes and Shleifer A., L. 1999. "Corporate ownership around the world". The Journal of Finance. 471517.

Laporta, R.,Lopez-de-Silanes and Shleifer A. and Vishy, R. 2000. "Investor protection and corporate governance", The Journal of Financial Economics, (2000), pp. 3-27.

Morck, R., Nakamura, M., Shivdasani, A. 2000. "Banks, Ownership Structure, and Firm Value in Japan". The Journal Of Business. 73 (4), 539-567.

Peraturan Bank Indonesia Nomor 8/4/PBI/2006 tentang Pelaksanaan Good Corporate Governance Bagi Bank Umum.

Peraturan Bank Indonesia Nomor:8/16/PBI/2006 tentang Kepemilikan Tunggal pada Perbankan Indonesia.

Shleifer, A., and Vishny, R. 1997. "A survey of corporate governance". The Journal of Finance. 737-783.

Supriyatno, 2006, Pengaruh Corporate governance dan Bentuk Kepemilikan Terhadap Kinerja Keuangan Bank di Indonesia, Disertasi pada Fakultas Ekonomika dan Bisnis, Universitas Gadjah Mada, Yogyakarta.

Surat Edaran Bank Indonesia Nomor 9/12/DPNP tanggal 30 Mei 2007 tentang Pelaksanaan Good Corporate Governance bagi bank umum.

\section{LAMPIRAN}

Lampiran 1. Persentase Kepemilikan Perbankan

\begin{tabular}{|c|c|c|c|}
\hline No & Nama Perusahaan & Pemilik Mayoritas & $\begin{array}{c}\text { Besarnya } \\
\text { Kepemilikan } \\
(\%)\end{array}$ \\
\hline 1 & PT Bank Agroniaga Tbk. & $\begin{array}{lr}\text { PT Bank } & \text { Rakyat } \\
\begin{array}{l}\text { Indonesia } \\
\text { Tbk }\end{array} & \text { (Persero) } \\
\end{array}$ & 79,78 \\
\hline 2 & PT Bank ICB Bumiputera Tbk. & $\begin{array}{l}\text { ICB Financial Group } \\
\text { Holding AG }\end{array}$ & 69,9 \\
\hline 3 & PT Bank Central Asia Tbk & $\begin{array}{l}\text { Bambang Hartono dan } \\
\text { Robert Budi Hartono }\end{array}$ & 47,15 \\
\hline 4 & PT Bank CIMB Niaga Tbk. & $\begin{array}{l}\text { CIMB Group Sdn Bhd, } \\
\text { Malaysia }\end{array}$ & 96,92 \\
\hline 5 & PT Bank Danamon Tbk. & $\begin{array}{l}\text { Asia } \quad \text { Financial } \\
\text { (Indonesia) Pte., Ltd. }\end{array}$ & 67,37 \\
\hline 6 & $\begin{array}{l}\text { PT Bank Ekonomi Rahardja } \\
\text { Tbk. }\end{array}$ & $\begin{array}{l}\text { HSBC Asia Pacific } \\
\text { Holding (UK) Limited }\end{array}$ & 98,94 \\
\hline 7 & $\begin{array}{l}\text { PT Bank Himpunan Saudara } \\
1906 \text { Tbk. }\end{array}$ & Ir. H. Arifin Panigoro & 52,92 \\
\hline 8 & $\begin{array}{l}\text { PT Bank } \quad \text { Internasional } \\
\text { Indonesia Tbk. }\end{array}$ & $\begin{array}{l}\text { Sorak Financial } \\
\text { Holdings Pte., Ltd. }\end{array}$ & 54,33 \\
\hline 9 & PT Bank Mega Tbk. & PT Mega Corpora & 57,82 \\
\hline 10 & PT Bank OCBC NISP Tbk. & $\begin{array}{l}\text { OCBC Overseas } \\
\text { Investment Pte., Ltd. }\end{array}$ & 85,06 \\
\hline 11 & $\begin{array}{lcl}\text { PT } & \text { Bank } & \text { Nusantara } \\
\text { Parahyangan Tbk. } & \end{array}$ & ACOM CO., LTD & 60,31 \\
\hline 12 & $\begin{array}{l}\text { PT Bank of India Indonesia } \\
\text { Tbk. }\end{array}$ & Bank of India & 76 \\
\hline 13 & PT Bank Permata Tbk. & $\begin{array}{l}\text { PT Astra International } \\
\text { Tbk. }\end{array}$ & 44,515 \\
\hline 14 & PT Bank Pundi Indonesia Tbk. & PT Recapital Securities & 74,69 \\
\hline 15 & PT Bank QNB Kesawan Tbk. & Qatar National Bank & 69,59 \\
\hline 16 & PT Bank Sinarmas Tbk. & $\begin{array}{l}\text { PT Sinar Multi Artha } \\
\text { Tbk. }\end{array}$ & 56,48 \\
\hline 17 & $\begin{array}{l}\text { PT Bank Windu Kentjana } \\
\text { International Tbk. }\end{array}$ & Johnny Wiraatmadja & 67,06 \\
\hline
\end{tabular}

Sumber: Indonesian Capital Market Directory (2011) 
Lampiran 2. Persentase Kepemilikan Perusahaan Pembiayaan Selain Bank

\begin{tabular}{|c|l|l|c|}
\hline No & \multicolumn{1}{|c|}{ Nama Perusahaan } & \multicolumn{1}{|c|}{ Pemilik Mayoritas } & $\begin{array}{c}\text { Besarnya } \\
\text { Kepemilikan } \\
(\%)\end{array}$ \\
\hline 1 & $\begin{array}{l}\text { PT Adira Dinamika Multi } \\
\text { Finance Tbk. }\end{array}$ & $\begin{array}{l}\text { PT Bank Danamon } \\
\text { Indonesia Tbk }\end{array}$ & 95 \\
\hline 2 & $\begin{array}{l}\text { PT Batavia Prosperindo } \\
\text { Finance Tbk. }\end{array}$ & $\begin{array}{l}\text { PT Batavia Prosperindo } \\
\text { International }\end{array}$ & 95 \\
\hline 3 & PT Buana Finance Tbk. & PT Sari Dasa Karsa & 67,6 \\
\hline 4 & $\begin{array}{l}\text { PT Central Omega Resources } \\
\text { Tbk. }\end{array}$ & PT Jinsheng Mining & 77,15 \\
\hline 5 & $\begin{array}{l}\text { PT Clipan Finance Indonesia } \\
\text { Tbk. }\end{array}$ & PT Bank Pan Indonesia Tbk & 54,35 \\
\hline 6 & $\begin{array}{l}\text { PT Equity Development } \\
\text { Investment Tbk. }\end{array}$ & $\begin{array}{l}\text { Equity Global International } \\
\text { Ltd }\end{array}$ & 68,33 \\
\hline 7 & $\begin{array}{l}\text { PT Mandala Multifinance } \\
\text { Tbk. }\end{array}$ & PT Jayamandiri Gemasejati & 70,42 \\
\hline 8 & PT Sinarmas Multiartha Tbk. & $\begin{array}{l}\text { JBC International Finance } \\
\text { (MAU) Limited }\end{array}$ & 52,63 \\
\hline 9 & $\begin{array}{l}\text { PT Wahana Ottomitra } \\
\text { Multiartha Tbk. }\end{array}$ & $\begin{array}{l}\text { PT Bank International } \\
\text { Indonesia Tbk }\end{array}$ & 62 \\
\hline
\end{tabular}

Sumber: Indonesian Capital Market Directory (2011)
Lampiran 3. Persentase Kepemilikan Perusahaan Sekuritas

\begin{tabular}{|c|l|l|c|}
\hline No & \multicolumn{1}{|c|}{ Nama Perusahaan } & \multicolumn{1}{|c|}{ Pemilik Mayoritas } & $\begin{array}{c}\text { Besarnya } \\
\text { Kepemilikan (\%) }\end{array}$ \\
\hline 1 & PT Arthavest Tbk. & $\begin{array}{l}\text { PT Artha Perdana } \\
\text { Investama }\end{array}$ & 53,56 \\
\hline 2 & $\begin{array}{l}\text { PT Bhakti Capital Indonesia } \\
\text { Tbk. }\end{array}$ & $\begin{array}{l}\text { PT Bhakti Investama } \\
\text { Tbk }\end{array}$ & 89,58 \\
\hline 3 & PT Lippo Securities Tbk. & $\begin{array}{l}\text { Pacific Asia Holdings } \\
\text { Limited }\end{array}$ & 63,48 \\
\hline 4 & $\begin{array}{l}\text { PT Majapahit Securities } \\
\text { Tbk. }\end{array}$ & $\begin{array}{l}\text { PT Asia Sukses Mandiri } \\
\text { Sejati }\end{array}$ & 57,81 \\
\hline 5 & PT Reliance Securities Tbk. & $\begin{array}{l}\text { PT Asuransi Reliance } \\
\text { Indonesia }\end{array}$ & 54,44 \\
\hline 6 & PT Yulie Sekurindo Tbk. & PT Jeje Yutrindo Utama & 52,44 \\
\hline
\end{tabular}

Sumber: Indonesian Capital Market Directory (2011)

Lampiran 4. Persentase Kepemilikan Perusahaan Asuransi

\begin{tabular}{|c|l|l|c|}
\hline No & \multicolumn{1}{|c|}{ Nama Perusahaan } & \multicolumn{1}{|c|}{ Pemilik Mayoritas } & $\begin{array}{c}\text { Besarnya } \\
\text { Kepemilikan } \\
(\%)\end{array}$ \\
\hline 1 & PT Asuransi Dayin Mitra Tbk. & $\begin{array}{l}\text { PT Equity Development } \\
\text { Investment Tbk }\end{array}$ & 73,92 \\
\hline 2 & $\begin{array}{l}\text { PT Asuransi Harta Aman } \\
\text { Pratama Tbk. }\end{array}$ & $\begin{array}{l}\text { PT Asuransi Central } \\
\text { Asia }\end{array}$ & 61,36 \\
\hline 3 & PT Panin Financial Tbk. & PT Panin Insurance Tbk & 57,15 \\
\hline
\end{tabular}

Sumber: Indonesian Capital Market Directory (2011) 